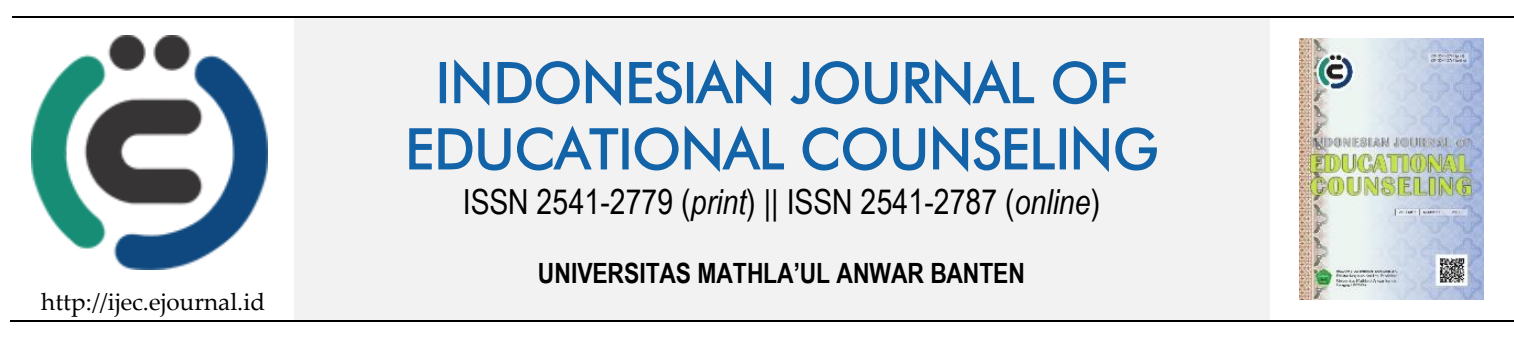

Research Based Article

\title{
Pengembangan Aplikasi Android Bantuan Diri (Self Help) dalam Perencanaan Pendidikan Lanjutan Siswa Kelas IX MTs Negeri 8 Banyuwangi
}

\author{
Rizki Iswar Annas ${ }^{1}$, Budi Purwoko², Tamsir Muis² \\ 1,2 Universitas Negeri Surabaya, Indonesia
}

\begin{tabular}{ll}
\hline Article History & ABSTRACT \\
\hline Received: 17.03.2021 & ANDROID APPLICATION DEVELOPMENT OF SELF HELP IN PLANNING \\
Received in revised form: & FOR FURTHER EDUCATION FOR CLASS IX STUDENTS OF MTS NEGERI 8 \\
09.06 .2021 & BANYUWANGI. This study aims to determine the development and feasibility \\
Accepted: 01.07 .2021 & of self-help android applications in the planning of advanced education for \\
Available online: 30.07 .2021 & students of MTsN 8 banyuwangi. The use of the research and development \\
& method contains ten stages, namely, gathering information and research studies \\
& and issues in the field, planning, developing the initial product or media form, \\
& validating the initial product or media stages, revising the product or media, \\
& testing the product, operational improvement product, operational testing \\
& phase, product improvement stage or final media, distribution and reporting. \\
& The results of research have produced an android application of self-help in the \\
& planning of further education for students of MTsN 8 Banyuwangi with the \\
& feasibility according to the results of research by media experts obtaining Very \\
& Good quality with a score of 46 (92\%), assessment from experts material obtains \\
& Very Good quality with a score of 46 (92\%), the assessment of the teacher (small \\
group) obtains Very Good quality with an average score of 64.67 and a \\
percentage of $92.3 \%$, the assessment of the teacher obtained very good quality \\
with an average score of 64.4 and a percentage of $92.28 \%$. When applied to \\
students in small groups, the average score was 35.8 with a percentage of $89.5 \%$. \\
While the results of the assessment of students in large groups obtained an \\
average value of 36.7 with a percentage of $91.75 \%$.
\end{tabular}

KEYWORDS: Android, Advanced Education Planning, Self Help.

DOI: $10.30653 / 001.202152 .160$

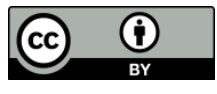

This is an open access article distributed under the terms of the Creative Commons Attribution 4.0 International License, which permits unrestricted use, distribution, and reproduction in any medium, provided the original work is properly cited. (c) 2021 Rizki Iswar Annas, Budi Purwoko, Tamsir Muis.

\section{PENDAHULUAN}

Setiap manusia yang lahir kedunia membutuhkan pengembangan untuk menjadi manusia yang seutuhnya sesuai yang diinginkan. Upaya pengembangan yang dilakukan adalah untuk mengembangkan potensi yang terdapat pada diri manusia itu sendiri, karena pada dasarnya manusia merupakan makhluk individu dan makhluk sosial. Dalam

${ }^{1}$ Corresponding author's address: Universitas Negeri Surabaya; Jl. Lidah Wetan, Lidah Wetan, Kec. Lakarsantri, Kota Surabaya, Jawa Timur 60213, Indonesia. E-mail: rizki.17071325007@mhs.unesa.ac.id 
kehidupanpun perlu adanya keseimbangan antara jasmani dan rohani serta kehidupan dunia dan akhiratnya. Manusia yang berkembang akhirnya akan dapat menjadi manusia yang berguna bagi masyarakat guna sebagai sumber daya manusia yang efektif bagi kehidupan yang maju dan dinamis.

Fase remaja adalah fase masa transisi peralihan dari masa kanak-kanak menuju masa dewasa. Menurut Hurlock (2014) Periode ini berpengaruh pada tahapan perkembangan segi emosi, sosial dan jasmani. Tugas perkembangan remaja menitik beratkan dalam menyiapkan dan menjalankan tuntutan serta peran menuju fase dewasa berkaitan langsung dengan pengetahuan, sikap, dan ketrampilan (tingkah laku dan tindakan) sebelum memasuki fase dewasa.

Oleh karena itu, peranan sekolah sangat penting, dalam upaya menyediakan berbgai program sebagai persiapan untuk memilih pendidikan lanjutan pada SMA, SMK, MA, atau Pondok Pesantren maupun dalam memberikan berbagai kegiatan bimbingan yang berhubungan dengan dunia pekerjaan. Saat ini kewajiban untuk memilih antara beberapa kemungkinan mendapatkan jabatan yang diinginkan dengan cepat, karena semakin tidak mungkin untuk menguasai beberapa bidang pekerjaan sekaligus. Maka, pelaksanaan kurikulum harus mampu dan siap sebagai wadah tantangan dan kebutuhan-kebutuhan yang memiliki rancangan tetap mempertimbangkan prinsip berkesinambungan berurutan dan integrase pengalaman. Hal ini agar sekolah mampu menyediakan lingkungan pendidikan bagi siswa untuk berkembang.

Saat ini pola pengajaran dibenturkan dalam keadaan yang memaksa setiap pendidik dan tenaga kependidikan agar bisa memahami dan mengaplikasikan metode daring dalam pembelajaran jarak jauh atau belajar dari rumah, terlebih lagi disaat terjadi pandemi wabah virus Covid 19. Dengan diberlakukannya aturan menjaga jarak (social distancing) mengakibatkan dilarangnya pembelajaran klasikal tatap muka pada satuan pendidikan, beberapa solusi yang bisa diambil adalah dengan menggunakan sistem pendidikan jarak jauh. Akan tetapi, hal tersebut menjadi suatu masalah mengingat lokasi, jarak biaya dan waktu berpengaruh besar pada masa ini (Kusuma, JW ; Hamidah:2020). Kondisi terjadinya pandemi wabah virus Covid-19 yang menyerang hampir seluruh belahan dunia tak terkecuali Negara kita Indonesia yang sampai saat ini belum berakhir, semua pendidik sebagian besar menggunakan pembelajaran jarak jauh tidak dengan tatap muka. Menurut Rahmawati (2016) kegiatan pembelajaran sekolah dapat dilaksanakan secara langsung maupun tidak langsung dengan menggunakan media pembelajaran daring ataupun media sosial, contoh dengan melakukan chatting memanfaatkan koneksi internet secara langsung maupun dengan berkirim email (tidak langsung) dalam hal mengumpulkan tugas ataupun pekerjaan rumah. Sebagai contoh sarana pembelajaran jarak jauh yang banyak digunakan yaitu media sosial seperti Whatsapp, Telegram, ataupun menggunakan aplikasi android seperti kipin, Elearning, Rumah belajar, google classroom dan lain-lain.

Dari pengisian angket yang disebarkan kepada murid kelas IX dan kelas VIII MTsN 8 Banyuwangi secara daring melalui google form dari 496 siswa terdapat 432 (87,1\%) menyatakan bahwa masih ragu untuk menentukan pilihan pendidikan lanjutan apakah melanjutkan ke SMA, SMK, MA ataupun Pondok pesantren dan menginginkan materi mengenai pengenalan terkait pilihan pendidikan lanjutan tersebut. Diketahui pula bahwa dalam pilihan penyampaian materi yang diinginkan peserta didik sejumlah $215(43,4 \%)$ siswa menginginkan materi disampaikan melalui aplikasi yang terinstal di smartphone, $123(24,8 \%)$ siswa menginginkan materi disampaikan dalam bentuk buku cetak, 106 
$(21,1 \%)$ siswa menginginkan bimbingan secara klasikal dan sisanya $51(10,3 \%)$ siswa menginginkan materi disampaikan secara virtual melalui aplikasi Zoom, Googlemeet. Dilihat dari kondisi lingkungan yang merupakan daerah strategis banyak terdapat sekolah ataupun madrasah di sekitar lokasi penelitian sebagai contoh diambil dari data Ditpontren Kemenag di Kabupaten Banyuwangi ada 113 podok Pesantren, untuk sekolah SMA dan MA ada 83 baik yang Negeri maupun Swasta dan 36 Sekolah Menengah Kejuruan, sangat disayangkan di Kabupaten Banyuwangi belum ada Madrasah Aliyah Kejuruan sehingga Madrasah Aliyah Kejuruan tidak termasuk dalam pilihan perencanaan pendidikan lanjutan siswa siswi di MTsN 8 Banyuwangi.

Berdasarkan masalah tersebut, maka peneliti merasa sangat penting untuk melakukan sebuah penelitian terkait pendekatan yang lain terkait perencanaan dalam memilih pendidikan lanjutan. Yang dilakukan peneliti dalam penelitian ini adalah pengembangan media aplikasi android bantuan diri (self help) dalam rangka membantu perencanaan pendidikan lanjutan siswa Madrasah Tsanawiyah (MTs). Aplikasi android bantuan diri (selp help) memiliki tujuan agar mampu mendukung dan mengarahkan peserta didik ataupun klien individu guna melakukan perencanaan pendidikan lanjutan, sehingga dapat meningkatkan kemampuan mengenal diri serta perencanaan karir, tidak terbatas pada hal yang bersifat informasi saja (Watkins \& Clum, 2007).

\section{METODE}

Proses yang peneliti lakukan menggunakan metode Pengembangan Research and Development $(R \mathcal{E} D)$. Sistem ini diaplikasikan merujuk pada langkah dan tahapan yang dikembangkan oleh Borg dan Gall (1989). Penelitian ini bertujuan menghasilkan suatu produk, menilai kefektifan produknya, dan membuka pengetahuan baru melalui penelitian dasar atau untuk menjawab pertanyaan-pertanyaan khusus tentang hal dimana bersifat praktis melalui penelitian terapan.

Tahapan terpenting dalam penelitian Research and Development $(R \in \mathcal{E})$ mempunyai perbedaan karakteristik jika dibandingkan dengan metode penelitian lainnya. Menurut Borg dan Gall (1983) ada empat perbedaan inti dari penelitian Research and Development $(R$ $\mathcal{E} D$ ) diterangkan yang pertama, pelaksanaan awal penelitian atau studi awal untuk menelusuri temuan dimana berhubungan dengan penelitian produk atau media yang selanjutnya akan dikembangkan. Berikutnya tahap kedua, adalah tahapan produk atau media yang akan dikembangkan berdasarkan dari temuan penelitian. Tahap tiga, pelaksanaan pengujian lapangan secara nyata berkaitan dengan pengembangan produk yang diterapkan. Tahap empat, pelaksanaan tahapan revisi atau perbaikan dari hasil pengujian lapangan agar kelemahan ataupun kekurangan bisa teratasi.

Penerapan penelitian Research and Development ( $\mathrm{R}$ \& D) didalam penelitian pengembangan aplikasi android bantuan diri (Self Help) untuk pemilihan pendidikan lanjutan siswa kelas IX MTsN 8 Banyuwangi didasarkan pertimbangan sebagai berikut:

Pertama, model penelitian Research and Development $(R \in \mathcal{E} D$ ) merupakan suatu model penelitian yang diawali dengan pengumpulan informasi serta isu, sementara paket bimbingan perencanaan pendidikan lanjutan yang dikembangkan dimulai dengan analisis kebutuhan siswa. Sehingga penggunaan penelitian Research and Development ( $R$ \& $D$ )dianggap sesuai dengan tujuan penelitian, yakni menghasilkan Aplikasi Andorid buku bantuan diri (Self Help) untuk pemilihan pendidikan lanjutan siswa kelas IX MTsN 8 Banyuwangi. 
Kedua, model penelitian Research and Development $(R \mathcal{E} D)$ cenderung simpel dan fleksibel karena bisa dipilih tahap mana saja yang cocok dengan keperluan dan tahap yang dirasa kurang sesuai dengan pengembangan Aplikasi Android bantuan diri (Self Help) untuk pemilihan pendidikan lanjutan siswa kelas IX MTsN 8 Banyuwangi yang tak terlalu kompleks.

Ketiga, diantara tahapan penelitian Research and Development $(R \& D)$ yakni uji lapangan dan revisi produk. Dalam hal ini amatlah cocok dengan paket bimbingan yang bersasarkan penilaian dan revisi atas produk yang dilakukan untuk menghasilkan Aplikasi Android bantuan diri Self Help) untuk pemilihan pendidikan lanjutan siswa kelas IX MTsN 8 Banyuwangi.

\section{HASIL DAN PEMBAHASAN}

\section{Pengembangan Media Ajar Berbasis Android}

Pengembangan media ajar android ini melawati tahapan 4D yaitu mulai define (pendefinisian), design (perancangan), develop (pengembangan), dan disseminate (penyebaran).

\section{Tahap Define}

Berdasarkan hasil observasi, wawancara dan penyebaran angket diatas maka peneliti ingin mengembangkan media ajar berbasis android. Hal ini dikarenakan media pembelajaran yang memanfaatkan smartphone ini sangat mudah dan dapat digunakan secara mandiri oleh siswa. Media pembelajaran dapat digunakan kapan saja dan dimana saja karena sifatnya portable. Proses penyebarannya cukup mudah karena ukurannya tidak lebih dari 66,04 MegaByte. Proses penyebarannya dapat menggunakan kabel data, bluetooth, email, whatsApp, untuk kemudian di install secara offline. Selain penggunaan secara mandiri oleh siswa, media pembelajaran dapat digunakan oleh guru di kelas dengan bantuan laptop/PC dan LCD. Namun, untuk menggunakan media ini di PC/laptop memerlukan bantuan emulato Android dan spesifikasi laptop yang mendukung karena akan sangat berpengaruh pada kelancaran untuk mengakasesnya.

Tahap Design

Pada tahapan desain setelah dilakukan analisis awal diperoleh desain penelitian dengan alur.

\section{Development}

Pada tahapan pengembangan ini, media android yang dikembangkan menggunakan lolipop edisi 2014. Berkas paket android (Application Package File, APK) adalah format berkas yang digunakan untuk emmasang atau menditribusikan dan memasang softaware dan middleware ke ponsel dengan sistem operasi android, mirip dengan paket MSI pada windows atau Deb pada OS Debian. Dalam hal ini untuk generasi sistem android yang dapat digunakan mulai dari lolipos edisi 2014, marshmallow, nougat, hingga generasi terupdate sekarang oreo. Dalam media ini dikembangkan lolipop edisi 2014 memiliki perangkat lunak (software) dan perangkat keras (hardware). Untuk pembuatan media berbasis Android memerlukan hardware dan software yang sesuai. Software yang digunakan untuk pembuatan media ini memiliki spesifikasi sebagai berikut: a) Power Point b) I spring Suite c) Web 2 APK d) Java Script e) Photoshopf) Cubase 5 g) Filmora 
Untuk hardware yang dibutuhkan untuk membuat perencanaan pendidikan lanjutan ini adalah a) Intel(R) Core(TM) i5 CPU b) RAM 4 GB c) Hard Disk 1 TB.

Selanjutnya desain pertama membuat halaman pembuka. Halaman Pembuka Loading screen berdurasi 5 detik. Setelah loading screen, maka akan muncul welcome screen, selanjutnya di buat halaman kedua. pada proses pengembangan diberikan angket penilaian kepada validator yaitu ahli materi, media dan praktisi. Berikut ini salah satu hasil validasi ahli media sebagai berikut:

\section{Hasil Validasi Ahli Materi}

Ahli media memberikan ceklist bahwa media dapat digunakan namun dapat di revisi sesuai saran.

\section{Tahap Desimination}

Tahap desiminasi dilakukan dengan menyebarkan media pembelajaran kepada siswa kelas IX MTs N 8 Banyuwangi.

\section{Uji Kelayakan}

\section{Validasi Media}

Berdasarkan penilaian oleh ahli media secara keseluruhan, aplikasi android (self help) mendapatkan nilai total 81 pada 23 indikator sehingga termasuk kategori sangat baik. Apabila dihitung dengan persentase, aplikasi berbasis android (self help) mendapatkan nilai $88,04 \%$, sehingga termasuk dalam kategori sangat layak untuk digunakan sebagai media pembelajaran.

\section{Validasi materi}

Berdasarkan penilaian oleh ahli materi secera keseluruhan, media mendapat nilai total 101 pada 27 indikator sehingga termasuk kategori sangat baik. Apabila dihitung dengan persentase, media mendapatkan nilai 93,51\% sehingga masuk dalam kategorisangat layak untuk digunakan sebagai media pembelajaran.

\section{Praktisi Guru Bimbingan Konseling}

Berdasarkan penilaian oleh guru bimbingan konseling secera keseluruhan, media mendapat nilai total 121 pada 31 indikator sehingga termasuk kategori sangat baik. Apabila dihitung dengan persentase, aplikasi android (selfhelp) mendapatkan nilai 97,58\% sehingga masuk dalam kategori sangat layak untuk digunakan sebagai media pembelajaran.

Siswa

Penilaian media pembelajaran juga dilakukan oleh 25 siswa di IX MTs N 8 Banyuwangi dengan menggunakan angket. Angket untuk siswa menggunakan skala Ghuttman dengan dua alternatif jawaban.

\section{SIMPULAN}

Pengembangan media ajar android ini melawati tahapan 4D yaitu mulai define (pendefinisian), design (perancangan), develop (pengembangan), dan disseminate (penyebaran). 
Berdasarkan penilaian oleh ahli materi secera keseluruhan, media mendapat nilai total 101 pada 27 indikator sehingga termasuk kategori sangat baik. Apabila dihitung dengan persentase, media mendapatkan nilai $93,51 \%$ sehingga masuk dalam kategori sangat layak untuk digunakan sebagai media perencanaan pendidikan lanjutan; b) dari ahli media berbasis android mendapatkan nilai $88,04 \%$, sehingga termasuk dalam kategori sangat layak untuk digunakan sebagai media perencanaan pendidikan lanjutan; c) Berdasarkan penilaian oleh guru bimbingan konseling secara keseluruhan, media mendapat nilai total 121 pada 31 indikator sehingga termasuk kategori sangat baik. Apabila dihitung dengan persentase, media mendapatkan nilai 97,58\% sehingga masuk dalam kategori sangat layak untuk digunakan sebagai media perencanaan pendidikan lanjutan; d) pada hasil field test diketahui bahwa seluruh pertanyaan mendapatkan "Respon Positif" dengan persentase $\geq 70 \%$ dengan rata-rata 95,3\% dari 6 item pertanyaan angket sehingga berada pada kategori sangat layak.

\section{REFERENSI}

Bergsma, A. (2008). Do self-help books help?. Journal of Happiness Studies, 9(3), 341-360.

Gardner, H. (2003). Multiple intelligences. Batam: Interaksara.

Hurlock, E. B.. (2004). Psikologi perkembangan. Jakarta: Gelora Aksara Pratama.

Kristanto. (2003). Perancangan sistem informasi. Yogyakarta: Gava Media.

Lewis, C., Pearce, J., \& Bisson, J. I. (2012). Efficacy, cost-effectiveness and acceptability of self-help interventions for anxiety disorders: systematic review. The British Journal of Psychiatry, 200(1), 15-21.

Marsudi, L. (2003). Psikologi pendidikan dan bimbingan . Malang: UNM Press.

McLean, S. (2013). Public pedagogy, private lives: Self-help books and adult learning. Adult Education Quarterly, 63(4), 373-388.

McLean, S., \& Vermeylen, L. (2014). Transitions and pathways: Self-help reading and informal adult learning. International Journal of Lifelong Education, 33(2), 125-140.

Riduwan. (2003). Dasar-dasar statistika. Cetakan ketiga, Bandung: Alfabeta.

Sharf, R. (1992). Applying career development theory to counseling. California: Brooks/Cole Publishing Company.

Simamora, H. (2001). Manajemen sumber daya manusia. Yogyakarta: Penerbit STIE YKPN.

Sukardi, D. K., \& Sumiati, D. M. (1993). Panduan perencanaan karier. Surabaya: Usaha Nasional.

Sukardi, D. K. (1987). Bimbingan karier di sekolah. Jakarta: Balai Pustaka.

Sukmadinata, N. S. (2010). Metode penelitian pendidikan. Bandung: Remaja Rosdakarya.

Supriatna, D. (2009). Pengenalan media pembelajaran. Bahan ajar untuk Diklat E-Training PPPPTK dan PLB. Bandung: PPPPTK dan PLB.

Supriatna, M., \& Budiman, N. (2009). Layanan bimbingan karier di sekolah menengah. Bandung: Departemen Pendidikan Indonesia. Universitas Pendidikan Indonesia. 
Walgito, B. (2010). Pengantar psikolog umum. Yogyakarta: Andi Offset.

(2012). Testing and assessment in counseling practice. Routledge.

Watkins Jr, C. E., \& Campbell, V. L. (2000). Testing and assessment in counseling practice. New Jersey: Lawrence Erlbaum Associates.

Wibowo. (2011). Manajemen kinerja . Jakarta: Raja Grafindo Persada.

Winkel, W. S., \& Sri Hastuti. (2006). Bimbingan dan konseling di institusi pendidikan. Jakarta: Grasi.

Winkel, W. S. (2004). Psikologi pendidikan dan evaluasi belajar. Jakarta: Gramedia Pustaka Utama. 